Collection: EFI 2008 Annual Conference Week - Orvieto (Italy) Adaptation of Forest Landscape to Environmental Changes Guest Editor: Giuseppe Scarascia Mugnozza (CRA - Rome, Italy)

\section{Forest and tourism: economic evaluation and management features under sustainable multifunctionality}

\section{Gios G, Clauser 0}

The ways in which forests have been used and managed by man have been modified substantially over time in relation to both changes in the economic and social needs of communities and the visions of the world that these have embraced. In recent times, as regards the flows of utility guaranteed by forests, increasing interest has been focused on recreational aspects of the landscape. Such interest derives from both the importance, highlighted by numerous studies, of this aspect and its connection with tourism. The latter phenomenon is undergoing strong growth and is able to trigger important processes of local development. Within this framework, the present study advances some preliminary considerations on the relationships which, from the standpoint of sustainable local development, exist between possible types of tourism and alternative methods of forest management. To this end, it first explores some characteristics of the forest landscape and their possible economic evaluation, in the light of the attributes of excludability and rivalry in consumption. The study then discusses the possible economic role of tourism and the contribution that a suitable forest landscape can make to the sector's development. Finally, it sets in context modes of forest management and alternative types of tourism development.

Keywords: Sustainable forest management, Tourism, Landscape, Public goods, Local development

\section{Introduction}

In the course of time, modes of forest use and management have changed greatly in relation to the evolution in the socio-economic needs of various communities (Koch \& Kennedy 1991), as well as in relation to the world views which influence those communities (Harrison 1992, Paci 2002). Specifically, after a period of time in which forests were a source of numerous useful products for local populations (Gorfer 1988) they have now become the source of a single product, namely timber. More recently, the demand on forests has progressively diversi-

Economics Department, University of Trento, v. Inama 5, I-38100 Trento (Italy)

@, Geremia Gios (geremia.gios@unitn.it)

Received: May 08, 2009 - Accepted: Sep 03, 2009

Citation: Gios G, Clauser O, 2009. Forest and tourism: economic evaluation and management features under sustainable multifunctionality. iForest 2: 192-197 [online: 200910-15] URL: http://www.sisef.it/ iforest/show. php?id=514 fied to include new aspects, for example, carbon fixing, giving different importance to functions once taken for granted, like the forest's role in the water cycle (Koch \& Kennedy 1991). Different social groups also sometimes assign contrasting significance to the forest itself (Hunziker 1995).

As a consequence of the above-mentioned evolution the basic concepts of forest management have also changed. This is because they can be considered as nothing other than 'the formulation at the scientific level of social issues which have, over time, been outlined (Paletto 2002). In parallel with concepts and management types, change has also taken place in the application methods which attempt to put the previous implications into practice. The result is that, at present, "those who are interested in forest management are required to have a broader vision of forestry so that many different social needs can be satisfied" (Reimoser 2005).

The emphasis on various economic, social and environmental functions is increasing at a time when the income derived from the use is a clear abandonment of forest cultivation of wood is decreasing. In consequence, there with major negative consequences (Paci 2002), as well as a search for alternative income sources. The latter are payments which derive either directly or indirectly from the positive externalities of forests. These revenues are obtained through public incentives or through mechanisms which obtain payment from the users themselves.

Although great efforts have been made within the framework of sustainable development to lay down universal guidelines for management methods able to ensure the maximisation of the social benefits produced by the forest itself, none have so far succeeded.

Many factors hamper identification of these guidelines: for example, the variability of forest ecosystems, the changes (in many cases very rapid) in the various stakeholders, each of them with different objectives in forestry management, the difficulties in evaluating the economic value of the various flows of utility that a forest produces. At the same time, other difficulties derive from the fact that, in economic terms, the various goods obtained from a forest have different characteristics.

Amongst the flows of utility that a forest generates, a key role is played by the landscape-recreational aspect. Indeed, according to the FAO (2005), $72 \%$ of European forests perform this function, which is also closely related to tourism, and this, as we know, is a growing phenomenon that can trigger important processes of local development (Pigliaru 1996).

This paper discusses the relationship between forests and tourism within the framework of sustainable development. To this end, the argument has been divided into six parts. The first is an in-depth investigation of some of the landscape's characteristics and their classification in relation to the attributes of excludability and rivalry in consumption. The second part reports some economic evaluations of forests' landscape-recreational value. The third part is an analysis of several instruments which can be implemented to transform the landscape externality into a source of income for those who manage the forests. The fourth part discusses the possible economic role of tourism from the perspective of local development and in the organisational models of tourist systems. The fifth part offers some considerations on forest management. Part six concludes.

\section{Landscape components and utility flows}

It is well known that the various utility flows that forests produce exhibit different characteristics in relation to the attributes of rivalry and excludability, which, when considered jointly, produce clusters of goods 
with similar economic characteristics. If we consider these two attributes and examine their most recent evolution, we can understand how a substantial change has come about at a general level within the forest. In the Western world, consideration of the forest as a source of private good, such as timber, has gradually given way to its increasing importance in the supply of public and semi-public goods. In fact, up until fifty years ago, forestry developed in a way in which the primary interest was in wood production, while the cost of labour was low; today that has changed, so it is necessary to take advantage of the natural opportunities in a way which at the same time maximises mass production and quality in the least expensive way (Paci 2002).

Among those opportunities is the forest's crucial role in formation of the landscape Nevertheless, implicit recognition of the forest's role in regard to the landscape has not always been followed by coherent policies for the management of forests.

The importance of the landscape is obvious, but it is more difficult to give it a universal definition. In fact, the term "landscape" traverses many fields of knowledge (Novelli 2005), is susceptible to a variety of meanings (Distasio 1998), and allows different ideas and knowledge to be connected with one another (Deffontaines 2004). Moreover, the concept that the rural landscape is a "permanent creative process" (Tabet 1963) implies on the one hand that analysis of the landscape must take account of the factors which produce the landscape transformation, and on the other that the evaluation must be performed in historical and dynamic terms, instead of being restricted to a static analysis based solely on aesthetics.

In this regard, Vos \& Meekes 1999, when referring to the rural landscape, and therefore implicitly to the role of the forest landscape maintain that 'People are shopping in the landscape'. In this framework it can be argued that if the landscape is an utility for those who enjoy it, the relative demand for it becomes quite complex and "...can be satis- fied by a heterogeneous mosaic of landscape types, characterized by variable modalities and intensities of man's interventions, but with forms and functions equally desirable in different social contexts" (Price 1978).

From the point of view of demand, the value of rural landscape can be considered as the sum of three main components: scenic (or landscape) value, recreational value, and nostalgic (or evocative) value. Unlike the first two, the last component is not connected to direct use of the good (Dillman \& Bergstrom 1991).

Scenic value, combined with aesthetic quality, is in its turn composed of various elements, which some authors (Price 1978, Van den Berg \& Wlek 1998) identify as quality, normality, peculiarity, diversity, stability, whereas others (Kaplan 1979) consider the relevant elements to be coherence, legibility, complexity, mystery. Finally, in a few cases (Tempesta \& Thiene 2006), emphasis is placed on the role which specific elements may have in modifying the level of appreciation that a certain landscape can arouse.

Therefore, the complexity of the mosaic which makes up the landscape is such that even in economic terms it can be considered as a group of goods rather than a precisely identifiable product. This situation applies to other flows of utility produced by forests as well. Consider the case of biodiversity. The result is that, even in relation to the attributes of excludability and rivalry, different "products" of the forest can be classified into different clusters, as illustrated in Tab. 1.

In almost all cases, the interaction between tourist activity and the forest landscape operates through consideration of the latter as a support for recreational activities. It is accordingly useful to start by attempting to classify the roles that a forest landscape may perform within different types of recreational areas. For this purpose, only use values will be considered, which means the recreational and scenic components of the landscape.

It is necessary to reclassify these components in the light of work by Clawson et al. 1960. Depending on one's perspective, forests can be wholly or partially useroriented or resource-based recreational areas, or they may even assume the function of a background.

In the first case, the forest (or elements of it) becomes a specific resource with which to attract the attention of tourists. An example is provided by acrobatic parks. The area occupied is usually relatively small, and it is possible to gain exclusivity of its use and utilise it for tourism initiatives which do not belong to a system. In the second case, the forest constitutes a generic resource for tourism, even if it is not always replaceable. It can be regarded as an element of the scenario in which different elements of the supply are located in order to make up the tourist destination. The area occupied is generally very large but delimited by sufficiently identifiable borders. It is not possible to have use exclusivity and there may be cases of congestion. In the third case, the forest is not perceived as a decisive element in the tourist supply, although it is an important factor in determining the overall attractiveness of the tourist destination. The area occupied is generally large, situated away from the central zones of the tourist destination and not clearly delimited to the observer. It is obviously not possible to have exclusivity, but cases of congestion are unlikely.

\section{Economic evaluation of the landscape-recreational component of the forest}

The bulk of research conducted to give a value to the landscape-recreational function of forests - in order to simplify the complex analytical framework and to overcome the difficulties of assigning weights to the various components - has sought to obtain the values attributed to forests by visitors. The surveys carried out for this purpose are numerous. In Italy alone, during the period between 1982 and 2005 (Paletto 2002, Novelli 2005), at least 40 surveys of this type were conducted. There are, however, far fewer monetary evaluations of the landscape as such: for example, Tempesta \& Thiene (2006) count 39 surveys on this topic relative

Tab. 1 - Flows of utility generated by the forest. Source: Our elaboration on OECD 2001.

\begin{tabular}{|c|c|c|c|}
\hline Goods & Non-rival & Congestible & Rival \\
\hline Non-excludable & $\begin{array}{l}\text { Purely public goods: } \\
-\mathrm{CO}_{2} \text { fixation } \\
\text { - elimination of pollutants } \\
\text { - landscape (non-use values) }\end{array}$ & $\begin{array}{l}\text { Open access resources: } \\
\text { - landscape (in resources-based } \\
\text { recreational areas) }\end{array}$ & - \\
\hline $\begin{array}{l}\text { Excludable to } \\
\text { outsiders of a } \\
\text { community }\end{array}$ & $\begin{array}{l}\text { Local public goods: } \\
\text { - hydro-geologic protection } \\
\text { - regulation of the water cycle } \\
\text { - landscape (scenic component) }\end{array}$ & $\begin{array}{l}\text { Common property resources: } \\
\text { - hunting }\end{array}$ & - \\
\hline Excludable & $\begin{array}{l}\text { Toll goods: } \\
\text { - landscape (option values) }\end{array}$ & Club goods & $\begin{array}{l}\text { Private goods: } \\
\text { - timber } \\
\text { - landscape (in recreational areas user-oriented) }\end{array}$ \\
\hline
\end{tabular}


Tab. 2 - Value of timber production and landscape-recreational function (euro/ha). Source: Our calculations based on Merlo \& Croitoru 2005.

\begin{tabular}{ccccc}
\hline Country & $\begin{array}{c}\text { Industrial } \\
\text { roundwood }\end{array}$ & Firewood & $\begin{array}{c}\text { Recreation } \\
\text { value of parks }\end{array}$ & $\begin{array}{c}\text { Recreation } \\
\text { value of forests }\end{array}$ \\
\hline Croatia & 75.8 & 12.7 & 450.0 & - \\
France & 72.8 & 16.4 & - & 114.5 \\
Greece & 8.4 & 5.1 & 12.0 & - \\
Italy & 24.3 & 26.4 & - & $19.7-48.8$ \\
Portugal & 130.5 & 11.3 & - & 4.9 \\
Spain & 27.8 & 1.5 & 95.0 & - \\
Slovenia & 76.0 & 10.3 & - & - \\
\hline
\end{tabular}

to Europe and only a few of them concern forests.

The findings of the above-mentioned studies can be generalised only with caution, given that the scenario in which the research is conducted is of great relevance. Amongst other things, owing to the survey methodology used in many cases only the value per visit is determined with no reference made to values by surface area. This obviously makes the values obtained more difficult to use for management purposes. In fact, it has been emphasised that preferences regarding the same landscape vary considerably if it is presented to the respondents as existing or as deriving from a potential transformation process (Hunziker 1995).

The availability of a significant number of surveys, however, allows one to gain an order of magnitude of the landscape value of forests. For example, by analysing 38 surveys conducted in Italy between 1982 and 2006, and stating the values in 2007 prices, one can determine that the value for each visit varies between 1.26 and 32.88 euros, with an average value of 8.21 euros. This average is influenced by a few particularly large values. In fact, almost half of the values found fell between three and five euros per visit.

The values obtained in the surveys mentioned above are probably overestimated in respect of the average values to be found in all forests, owing to the fact that the surveys were probably conducted in areas of particular importance to the aspect analysed. Nevertheless, they are interesting values, as confirmed by comparison of the landscaperecreational and the timber production values of the same forests. Similar comparison can be made with regard to the forests of some Mediterranean countries (see Tab. 2 and Tab. 3 for Italian forests).

Finally, regarding the problems of management and local development, it is advisable to bear in mind an aspect of landscaperecreational values related to capital intensity. The landscape-recreational values appear high if we compare them with those related to timber production, but they are very low if we compare them with those guaran- teed by alternative forms of land use. In order to produce adequate income for today's needs, therefore, large surfaces are required for timber production. Such surfaces are not always available, either because the firms are too small or because they are not compatible with adequate local development, which requires a sufficient population density. Finally, alternative uses, even for tourism, may be of interest and may create conflicts in relation to the planned land use.

\section{Instruments to internalise positive landscape externalities}

The increasing economic weight of the forest in landscape-recreational terms is accompanied on the one hand by the growing importance of tourism within the European economic system, and on the other by the fact that those affected by utility flows produced by the forest are segments of the population increasingly distant from it.

This evolution has created numerous problems largely because of the simultaneous reduction in the profitability of the forest as a timber producer. This phenomenon has stimulated a search for alternative sources of income in order to prevent the abandonment of the forest which causes numerous environmental, economic and social problems in broad areas such as the alpine regions.

At the same time, this evolution obviously requires management methods and instruments which differ from those of the past and which may generate conflicts among different uses and among potential beneficiaries.

This consideration also applies to the landscape as a shared space in which different communities and individuals pursue a variety of goals, and with regard to which it is difficult, if not impossible, to identify pro-

Tab. 3 - Value of timber production and landscape-recreational function (euro/ha). Source: (a) Paletto 2002, (b) Gios et al. 2008, (c) Marangon \& Gottardo 2001.

\begin{tabular}{lccc}
\hline \multicolumn{1}{c}{} & Oulx Municipality $^{(\mathbf{a})}$ & Trento Province $^{(\mathbf{b})}$ & Friuli Region $^{(\mathbf{c})}$ \\
\hline Timber production & 40.01 & 94.47 & 137.4 \\
Utilised production & n.a. & 45.86 & n.a. \\
Landscape recreational & 55.16 & 47.94 & 158.9 \\
value & & & \\
\hline
\end{tabular}

\section{value}

perty rights. The landscape can therefore become controversial and raise numerous issues, such as the methods used to allocate the resources necessary for its production, definition of the subjects entitled to decide such matters, and how those to be paid for their conservation should be compensated.

A pleasant landscape is a positive externality of human activity and, in our case, of forest activity. How a forest is managed greatly influences the degree of landscape appreciation. At the same time, timber production and the landscape represent a joint production. Generally speaking, improvement of the landscape function increases the costs of and/or reduces timber production, with a consequent fall in income for owners of the forests and, if other compensating factors do not come into play, impoverishment of the local population.

In order to identify suitable measures with which to quantify positive landscape externalities produced by the forest together with other public goods, we can proceed from two different starting-points. The first requires that there is a reward at least equal to the higher costs (or lower profits) that the forester receives from conserving a pleasant landscape. The second requires that landscape 'production' be paid by an amount equal to that of the benefits produced. Of course the two solutions imply different evaluations of the propriety right connected with the natural good "landscape"

Without going further into this aspect, although it may be of some importance from an application perspective, we can state that the available economic policy tools can be grouped into three different sets of intervention methods.

The first seeks to internalise the positive externalities produced by obliging those who use them to pay for them. The second consists of compensatory interventions granted by a public body. The third operates within the framework of local development and uses instruments derived from the management of common property resources.

These three types of intervention are not always mutually exclusive; rather, they are complementary to each other, or better they can be used in function of the characteristics of the forest landscape considered and of the economic system in which the landscape is embedded. To illustrate this, below are some brief considerations on tourism within the local development process, as well as on the 
possible connection between the landscape and recreational activity with regard to tourism.

\section{Tourism and local development}

It is well known that tourism is not a welldefined production activity but rather an aggregate of services and activities from various economic sectors. The nature of the tourism product is extremely composite and complex (Della Corte 2000, Rispoli \& Tamma 1995). It is characterised by a type of use related to the features of the environment and by the fact that the activities of several players form a system (Tamma 2002). At the same time, the impact that tourism itself produces is also systemic, given that the tourism industry tends to involve the entire economy of the territory in which it operates, with effects of a social, cultural and environmental nature (Clauser et al. 2001).

Like many other sectors, tourism has undergone radical changes (Ejarque 2003, Godfrey \& Clarke 2000). On the demand side, these changes have produced an increase in tourist interest in nature, and on the supply side, growing awareness that nature and territory are resources which must be managed sustainably and not indiscriminately (Godfrey \& Clarke 2000).

It is evident that tourism can be an important factor in local development. For this to occur, however, three fundamental conditions must be in place (Rispoli \& Tamma 1995, Tamma 2002):

- presence of attractiveness factors, i.e., resources of various kinds able to stimulate demand;

- uniform vision of the area with a geographically identified territory;

- cooperation among the actors involved with a view to an integrated supply.

Nonetheless, tourism supply is often not structured in the best possible way. In fact the configurations of the supply can be (Brunetti 1999):

- sectorial (not systemic), when the relationships among the subjects involved are random and unplanned;

- weakly systemic, when the supply actors feel that they are part of a uniform body, even if it is only a "loosely coupled" one;

- strongly systemic, when the actors are connected in a local tourist supply system in which the relationships among the subjects involved are institutionally planned.

It is obvious that in the first case there is room for some tourist activities, but not for a tourist system. The different configurations are important, however, even for selecting the tools with which to internalise the benefits produced by the forest landscape, as shown in more detail below.

\section{Different approaches to forest management}

Awareness of the forest's ability to perform many functions has led over the years to identification of various principles on which forest management should be based. In relation to the evolution of society's needs, new management schemes have been developed for the purpose of multiple use management, multifunctional forest management, and ecosystem management.

Multiple use management (Fernand 1995) centres on cultivation techniques for the uses and the utilities that goods and services supplied by the forest provide for man. Some techniques of multiple use management are multi-purpose land use, multi-user forest management (Buttoud 2002) and multi-beneficiary forest management. These last two variants have been devised to satisfy growing demand for participation in the planning of cultivation and use operations. Planning is no longer the exclusive task of forest technicians but now also involves the users or beneficiaries. In application of the previously-mentioned principles, two different cultivation techniques have been developed, one consisting of large-scale segregation (Pearson 1944), the other of complete integration and equal priorities (Dana 1943). The former provides for zoning and for time segmentation in areas designed for a single prevalent use. The second envisages the simultaneous pursuit of all uses across the entire area. There is also an intermediate technique: small-scale segregation, which consists of designing small areas for single prevalent uses (Helliwell 1987).

The goal of multifunctional forest management (Hytönen 1995) is to optimise the functions of forests regardless of whether they are more or less useful for man. Compared with multiple use management, the time frame is wider. The management methods incorporating these principles are goaloriented and they comprise so-called integrated forest management (Jeffrey et al. 1970, Erdle 1996). Unlike multi-user and multi-beneficiary forest management, when this method is used, the role of forest technicians becomes more important because they can only indirectly take the needs of different social actors into account. These principles underlie the wake theory (Koch \& Kennedy 1991, Merlo \& Rojas Briales 2000). In this case, it is believed that maximising timber production will bring improvements in all other functions, so that multi-functionality is consequently optimised.

In ecosystem management (Behan 1990), the planning of cultivation is not restricted to single functions but considers the ecosystem in its entirety, including all possible existing interconnections. The management method incorporating these principles is based on continuously monitored and revised plans. Participation in the management process of all stakeholders is envisaged, and the attainable results are evaluated from the landscape standpoint.

\section{Forest management, landscape and tourism}

Forest management is therefore a way to maintain the balance of a complex system in which there are joint forms of production and goals and constraints which are partially conflicting. This conflict may arise within a forest system or even on a territorial scale with other economic agents operating in the same area. Therefore, if the purpose is to obtain efficiency and sustainability, it is essential to identify the relevant aspects and to use mutually consistent instruments. Of course, operating in this way requires bearing in mind the constraints which arise from the many objectives and players involved and which become much more incisive when the latter are numerous, whereas efficiency in achieving a single objective does not always represent a necessary condition for obtaining the global efficiency of the entire system.

If examination is restricted to aspects regarding the relationships among forest management, landscape and tourism, the following conclusions can be drawn.

In cases where the forest landscape represents a specific resource (as illustrated in section 5) for tourist activity, the solution for the internalisation of the positive externalities produced is of Coasian type; that is, it is based on introduction of entry tickets paid by users. This solution appears to be applicable to small forest areas, including those with particularly interesting natural features, or those in which major investments have produced specific infrastructures (for example, those relative to acrobatic parks). In this case, multiple use management appears to be the most suitable managerial method to adopt. The presence of conditions enabling reliance on specialisation and economies of scale suggests that, in the majority of cases, the technique of large-scale segregation should be employed. Less frequently, and in the context of cases in which the additional investments are extensive (for example, pay trails connecting panoramic points, presence of biodiversity, areas dedicated to the gathering of underbrush products, etc.), it may be advisable to employ the equal priorities technique, because this is based on principles of economy of scope. This course of action is also compatible with tourism initiatives which are relatively isolated and not integrated into a system (although it would be of greater advantage if they were).

When the forest landscape represents a background scenario, the solution can only be a compensation of public nature. Case studies on public intervention are too nume- 
rous and too well-known to require furthe analysis here. Suffice it to mention the measures put in place by the European Union. From the forest management standpoint, it seems reasonable to operate within the multifunctionality framework, given that the interest in conserving the landscape externality appears to be widespread, but without it being a decisive factor for any of the stakeholders involved and consequently of little relevance to the definition of forest management methods. This interest, moreover, is held not only by tourists and tourist operators but also by residents and, owing to conditions of reduced excludability and rivalry, one comes close to the situation of a purely public good. If there are no problems in guaranteeing the other forest functions, it is helpful to refer to the wake effect. Among other things, it can be argued that maximising the biomass will guarantee better coverage of the surface and consequently generate a better "background" effect. Finally, from the tourism system standpoint, the feature which best describes this is the presence of weak ties among the various actors involved.

When the landscape is a scenario, and not just a simple production input, and directly enters into the function of visitor utility, producing a trade-off between resource consumption and supply quality (Pigliaru 1996), it is necessary to use the forest for the purpose of local development. Participation by all actors in the definition of goals is absolutely necessary. In recent times, among the methods piloted in relation to the rural landscape in its entirety are those relating to management agreements and maintenance agreements in the English-speaking countries, and those relating to cultivation contracts in France. With reference to forests, we can mention Scotland and England. Some of the first schemes of this kind, however, have encountered problems (Whitby \& Saunders 1996). Among those specifically aimed at the forest world are the community forests (Colangelo $G$ et al. 2006) which arose from institutional planning and are characterised by intense participation. This approach appears very interesting because, when certain conditions are met (Pieraccini 2008), it is possible to revitalise old experiences of collective management regarding vast forest areas in many European countries. Moreover, it seems well-established (Gios \& Raffaelli 2003) that different areas are subject to objective conditions (relating to the resource to be managed) and subjective conditions (relating to the users of the resource), which, according to Ostrom (Ostrom 1990, Ostrom 1998), increase the likelihood that self-governing organisations will emerge to manage open access resources and influence the benefits attainable and the costs which must be incurred in order to ob- tain them. In this case, it seems preferable to plan an ecosystemic type of forest management by using the long-standing techniques of naturalistic forestry. This is a management method in which man is an active component of the ecosystem, undertaking the role of managing in order to maintain the ecosystem in a dynamic equilibrium. Obviously, this type of approach is possible only with organised tourism within a local system of tourist supply.

The three above-mentioned approaches are ideal models which are rather difficult to identify unequivocally in concrete situations. In the majority of cases, there will be situations in which the elements present will make it necessary to use several instruments simultaneously. In these cases, definition of the relative importance of the different goals and the capacity to use the appropriate instruments are of crucial importance to ensure the long duration of the chosen model management

\section{Concluding remarks}

As with other positive externalities produced by forest management, with the also it is difficult to internalise the benefits produced. In this regard, the possibility of introducing forms of payment to use landscape services seems restricted to a relatively small number of specific situations. Somewhat commoner seem to be areas in which the principle of collective ownership can be applied and in which payment is not made directly by those who use the landscape but rather by actors (hoteliers, shopkeepers, service firms) that benefit from the presence of the tourists. In all other cases remuneration of the landscape externality can only derive from action by the state.

Whatever the case may be, it is necessary to ensure coherence between the mode of forest management, the type of tourism, and the characteristics of the model of local development which are to be pursued. This objective is not easy to achieve, given that it is pursued within a complex situation where, besides the importance of individual factors, account must be taken of the relations among them. It is also necessary to bear in mind that this is a dynamic context in which the speed with which it is necessary to operate is not the same for the various systems considered. Specifically, the time necessary to ensure that changes in forest management are sustainable may be much longer than the time that the other actors involved in local development are willing to accept. This may generate conflicts and the necessity to operate by applying the precautionary principle.

Finally, one must emphasise that coherence between forest management, tourism and local development requires suitable policies that, amongst other things, imply the income redistribution from the actors who benefit to those who bear the costs of creating pleasant and appreciated landscapes.

\section{References}

Behan RW (1990). Multiresource forest management: a paradigmatic challenge to professional forestry. Journal of Forestry 88 (4): 12-18.

Brunetti F (1999). Il turismo sulla via della qualità. Cedam, Padua, Italy.

Buttoud G (2002). Multipurpose management of mountain forests: which approaches? Forest Policy and Economics, Special Issue on Multipurpose Management of Mountain Forests 4 (2): 83-87. - doi: 10.1016/S1389-9341(02)000084

Clauser O, Franch M, Gios G (2001). Compatibilità tra sviluppo della domanda di turismo invernale nelle Dolomiti e sostenibilità ambientale. In: "La Sardegna nel mondo mediterraneo: Quinto convegno internazionale di studi Turismo e Ambiente" (Scanu G ed). Sassari (Italy) 28-30 October 1998. Patron editore, Bologna, Italy.

Clawson M, Held B, Stoddard CH (1960). Land for the future. Johns Hopkins Universiy Press, Baltimore, USA.

Colangelo G et al. (2006). L'esperienza delle community forests in Inghilterra. Ri-Vista. Ricerche per la progettazione del paesaggio 4 (6): 1-10.

Dana ST (1943). Multiple use, biology and economics. Journal of Forestry 41 (9): 625-626.

Deffontaines JP (2004). L'objet dans l'espace agricole. Le regard d'un géoagronome. Natures Sciences Sociétés 12: 299-304. - doi: 10.1051/ nss:2004041

Della Corte V (2000). La gestione dei sistemi locali di offerta turistica. Cedam, Padua, Italy.

Dillman BL, Bergstrom JC (1991). Measuring environmental amenity benefits of agricultural land. In: "Farming in the countryside: an economic analysis of costs and benefits" (Hanley N ed). CAB International, Wallingford, UK.

Distasio M (1998). L'economia del paesaggio rurale. Agribusiness Paesaggio e Ambiente 1: 2239.

Ejarque J (2003). La destinazione turistica di successo. Marketing e management. Hoepli, Milan, Italy.

Erdle TA (1996). Elements of integrated forest management. Integrated Forest Management Workshop. [online] URL: http://mf.ncr.forestry.ca/conferences/ifm/erdleeng.html

FAO (2005). Global forest resources assessment 2005-15 Key Findings. FAO, Rome, Italy.

Fernand J (1995). Multiple-use forestry - A concept of communication. In: "Multiple-use forestry in the Nordic countries" (Hytönen M ed). The Finnish Forest Research Institute, Helsinki, Finland, pp. 67-80

Gios G, Goio I, Pollini C (2008). The development of forest accounting in the Province of Trento, Italy. Journal of Forest Economics 14: 177-196. - doi: 10.1016/j.jfe.2007.09.002

Gios G, Raffaelli R (2003). Lo strumento consortile per la gestione e lo sviluppo del territorio nelle aree montane. In: "Cosa apprendere dalla proprietà collettiva. La consuetudine fra tradi- 
zione e modernità" (Nervi P ed). Proceedings of the Meeting: "Cosa apprendere dalla proprietà collettiva. La consuetudine fra tradizione e modernità", Trento (Italy), 14-15 November 2002. Cedam, Padua, Italy, vol. 9: 175-195.

Godfrey K, Clarke J (2000). The tourism development handbook: a practical approach to planning and marketing. Thompson Learning, London, UK.

Gorfer A (1988). L'uomo e la foresta. Manfrini editore, Trento, Italy.

Harrison RP (1992). Foreste. L'ombra della civiltà. Garzanti editore, Milan, Italy.

Helliwell R (1987). Multiple-use of forestry in the United Kingdom. Ambio 16 (2-3): 129-133.

Hunziker M (1995). The spontaneous reafforestation in abandoned agricultural lands: perception and aesthetic assessment by locals and tourists. Landscape and Urban Planning 31: 399-410. doi: 10.1016/0169-2046(95)93251-J

Hytönen M (1995). History, evolution and significance of the multiple-use concept. In: "Multiple-use forestry in the Nordic countries" (Hytönen M ed). The Finnish Forest Research Institute, Helsinki, Finland, pp. 43-65.

Jeffrey WW, Brown CS, Jurdant M, Novakowski NS, Spilsbury RH (1970). Foresters and the challenge of integrated resource management. Forestry Chronicle 46 (3): 196-199.

Kaplan S (1979). Concerning the power of content identifying methodologies. In: "Assessment of amenity resources values" (Daniel TC, Zube EH eds). USDA Forest Service Rocky Mountains Station, USA.

Koch NE, Kennedy JJ (1991). Multiple-use forestry for social values. Ambio 20 (7): 330333.

Marangon F, Gottardo E (2001). La valutazione del danno ai boschi del Friuli Venezia Giulia. In: "La valutazione dei beni ambientali come supporto alle decisioni pubbliche" (Tempesta F, Marangon F ed). Ed. Forum, Udine, Italy, pp. 2742.

Merlo M, Croitoru L (2005). Valuing mediterranean forests. Towards total economic value. CABI Publishing, Wallingford, UK.

Merlo M, Rojas Briales E (2000). Public goods and externalities linked to mediterranean forests: economic nature and policy. Land Use Policy 17: 197-208. - doi: 10.1016/S0264-8377(00)00017-X Novelli S (2005). Aspetti economici e politici della conservazione del paesaggio rurale. Definizione dello strumento d'indagine per una valutazione economica nell'astigiano. Ph.D. thesis (XVI cycle), University of Turin, Italy.

OECD (2001). Multifunctionality - towards an analytical framework. OECD Publications, Paris, France.

Ostrom E (1990). Governing the commons: the evolution of institutions for collective action. Cambridge University Press, Cambridge, MA, USA

Ostrom E (1998). A behavioral approach to the rational choice theory of collective action. American Political Science Review 92: 1-22. - doi: $10.2307 / 2585925$

Paci M (2002). L'uomo e la foresta. Meltemi editore, Rome, Italy.

Paletto A (2002). Il valore economico totale come strumento di valutazione della multifunzionalità forestale. Un'analisi teorica e applicazione ai boschi del comune d'Oulx. Ph.D. thesis, University of Trento, Italy.

Pearson GA (1944). Multiple use in forestry. Journal of Forestry 42 (4): 242-249.

Pieraccini M (2008). La sostenibilità delle com- mon lands: (sotto)sviluppo storico dei meccanismi di governance. Archivio Scialoja-Bolla. Annali di Studi sulla Proprietà Collettiva 1: 61-84.

Pigliaru F (1996). Economia del turismo: note su crescita, qualità ambientale e sostenibilità. Contributi di Ricerca CRENoS 12.

Price C (1978). Landscape economics. Macmillan, London, UK.

Reimoser F (2005). Il ruolo della selvicoltura nella gestione faunistica. Sherwood 112: 19-23.

Rispoli M, Tamma M (1995). Risposte strategiche alla complessità: le forme di offerta dei prodotti alberghieri. Giappichelli, Turin, Italy.

Tabet D (1963). La rendita fondiaria nell'agricoltura italiana, Editori Riuniti, Rome, Italy.

Tamma M (2002). Destination management: gestire prodotti e sistemi locali di offerta turistica In: "Destination management. Governare il turismo tra locale e globale" (Franch M ed). Giappichelli, Torino, Italy, pp. 11-38.

Tempesta T, Thiene M (2006). Percezione e valore del paesaggio. Franco Angeli, Milan, Italy.

Van den Berg AE, Wlek CAJ (1998). The influence of planned-change context on the evolution of natural landscapes. Landscape and Urban Planning 43: 1-10. - doi: 10.1016/S01692046(98)00102-9

Vos W, Meekes M (1999). Trends in European cultural landscape development: perspectives for a sustainable future. Landscape and Urban Planning 46 (1-3): 3-14. - doi: 10.1016/S01692046(99)00043-2

Whitby M, Saunders C (1996). Estimating the supply of conservation goods in Britain: a comparison of the financial efficiency of two policy instruments. Land Economics 72 (3): 313-325. doi: $10.2307 / 3147199$ 